\title{
Perilaku Prososial Ditinjau dari Rasa Syukur pada Persaudaraan Muda-Mudi Vihara Borobudur (PMVB) Medan
}

\author{
Sushella Salihin \\ Fakultas Psikologi, Universitas Prima Indonesia \\ sushella16@gmail.com \\ Nurmaizar Nilawati Siregar \\ Fakultas Psikologi, Universitas Prima Indonesia \\ nilawati_siregar@unprimdn.ac.id \\ Achmad Irvan Dwi Putra \\ Fakultas Psikologi, Universitas Prima Indonesia \\ achmadirvandwiputra@unprimdn.ac.id
}

\begin{abstract}
Prosocial behavior is an effort to improve welfare and harmony in the social life of the community. This study aims to determine the effect of gratitude on prosocial behavior in the Young-Mudi Brotherhood of Borobudur Temple, Medan. This research was conducted on 149 young people who had joined for one year and aged 18-40 years. The hypothesis in this study was that there was a positive relationship between gratitude and prosocial behavior. Hypothesis testing uses the Pearson Product Moment Correlation technique after an assumption test that includes tests of normality and linearity through the help of SPSS 21 for windows. The results of data analysis showed a correlation coefficient of 0.551 ( $p<0.000)$. This shows that the gratitude of young people has a positive and significant effect on prosocial behavior.
\end{abstract}

Keywords: gratitude; prosocial behavior

\begin{abstract}
Abstrak
Perilaku prososial merupakan upaya untuk meningkatkan kesejahteraan dan kerukunan dalam kehidupan sosial masyarakat.Penelitian ini bertujuan untuk mengetahui pengaruh rasa syukur terhadap perilaku prososial pada Persaudaraan Muda-Mudi Vihara BorobudurMedan. Penelitian ini dilakukan terhadap 149 muda-mudi yang telah bergabung selama satu tahun dan berusia 18 - 40 tahun.Hipotesis dalam penelitian ini adalah ada hubungan positif antara rasa syukur dengan perilaku prososial. Pengujian hipotesis menggunakanteknik Pearson Product Moment Correlationsetelah dilakukan uji asumsi yang meliputi uji normalitas dan linearitasmelalui bantuan SPSS 21 forwindows. Hasil analisis data menunjukkan koefisien korelasi sebesar $0,551 \quad(\mathrm{p}<0,000)$. Hal ini
\end{abstract}


menunjukkan bahwa rasa syukur muda-mudi berpengaruh secara positif dan signifikan terhadap perilaku prososialnya.

Kata Kunci: rasa syukur; perilaku prososial

\section{Pendahuluan}

Di era globalisasi seperti saat ini membawa perubahan yang cukup signifikan dalam berbagai aspek kehidupan manusia seperti adanya perubahan pada pola interaksi antar individu dan perubahan nilai dalam kehidupan bermasyarakat. Era globalisasi terkait erat hubungannya dengan perkembangan teknologi yang pesat, dimana hal tersebut memunculkan masalah baru pada aspek pergaulan dan perilaku masyarakat masa kini seperti munculnya sikap individualis masyarakat. Di masa sebelum masuknya arus globalisasi serta kecanggihan teknologi, Indonesia merupakan negara yang mempunyai nilai sosial yang tinggi.

Rendahnya kepedulian masyarakat terhadap sesama tidak mencerminkan individu sebagai mahkluk sosial yang memiliki kewajiban untuk saling tolongmenolong dan berbagi sebagai interaksinya dengan orang lain (Herimanto \& Winarno, 2017), padahal disekeliling kita masih banyak orang yang membutuhkan bantuan. Apabila masyarakat memiliki kepedulian terhadap orang lain, ini dapat memberikan manfaat kepada orang lain dan dirinya sendiri. Individu yang memberi, berbagi, dan membantu individu lain memiliki penghargaan bagi dirinya sendiri karena telah berbuat suatu kebaikan.Menurut Pujileksono, Abdurahman, Yuliani, dan Wuryantari (2018), kehidupan manusia di masyarakat pada dasarnya saling menolong karena hanya dengan cara demikian kelompok manusia dapat mempertahankan ekosistemnya. Oleh karena itu, manusia dalam hidup bermasyarakat harus senantiasa hidup bersama, saling menjaga dan bekerjasama. Dengan demikian, kesejahteraan serta kerukunan hidup dalam bermasyarakat akan mudah terwujud.

Perilaku-perilaku penunjang kesejahteran dan kerukunan bermasyarakat tersebut dapat disebut dengan perilaku prososial. Perilaku prososial adalah istilah umum untuk membantu orang lain, baik pada tingkat individu seperti membantu seseorang yang tersesat atau pada tingkat kelompok seperti menyumbang ke 
badan amal (Heinzen \& Goodfriend, 2019). Menurut Baron dan Byrne (2003), perilaku prososial adalah suatu tindakan nyata berupa bantuan yang dilakukan oleh individu terhadap orang lain atau kelompok yang akan mendatangkan keuntungan kepada penerima bantuan tersebut dengan mengenyampingkan keuntungan bagi si penolong ataupun bahkan mendatangkan kerugian baginya. Hal ini memiliki tujuan untuk menciptakan perubahan yang lebih baik, baik secara material maupun psikologis, terutama bagi penerima bantuan(William dalam Pitaloka\& Ediati, 2015).

Membantu orang lain mungkin adalah salah satu bagian terbaik dari jejaring sosial dan kita semua mungkin mengalami perasaan sukacita bahwa kita telah membuat perbedaan positif di dunia (Heinzen \& Goodfriend, 2019). Kaum muda yang terintegrasi secara sosial ingin menggunakan kekuatan unik mereka untuk memberi kembali kepada orang lain dan membuat dunia lebih baik (Froh, Bono,\& Emmons, 2010). Menurut Wilson (dalam Hogg \& Vaughan, 2011), saat ini banyak orang tertarik pada bentuk lain dari bantuan spontan, yaitu kegiatan sukarelawan, suatu kegiatan yang menjadi semakin penting bagi kebaikan umum. Salah satu kegiatan yang membutuhkan dan dapat meningkatkan perilaku prososial adalah dengan menjadi relawan. Relawan adalah seseorang yang menyumbangkan waktu, tenaga, dan bakatnya untuk memenuhi suatu kebutuhan masyarakat tanpa mengharapkan keuntungan finansial atas sumbangannya tersebut (Musick \& Wilson, 2008). Relawan sosial biasanya melakukan kegiatan sosial melalui perantara organisasi-organisasi yang terdapat di sekitarnya seperti organisasi keagamaan, organisasi pendidikan, dan organisasi pelayanan masyarakat.

Salah satu organisasi keagamaan di Kota Medan, yaitu Persaudaraan Muda-Mudi Vihara Borobudur (PMVB) Medan yang selalu melakukan acara keagamaan dan kegiatan-kegiatan sosial, seperti pelayanan umat, bakti sosial,dan donor darah. Setiap kegiatan organisasi selalu direncanakan dan dilaksanakan oleh para muda-mudinya. Berdasarkan wawancara dengan ketua dan humas PMVB mengatakan bahwa mereka memiliki banyak anggota, namun hanya 20-30\% yang aktif berpatisipasi dalam membantu kegiatan-kegiatan PMVB. Biasanya para 
muda-mudi baru hanya aktif dalam enam sampai tujuh bulan dari pertama mereka bergabung. Kesulitan yang sering dihadapi oleh para koordinator acara adalah sulitnya mencari anggota, sehingga tidak jarang para koordinator mencari dari luar organisasi. Banyak muda-mudi yang hanya berkomentar dan mengkritik namun tidak ada inisiatif untuk membantu muda-mudi lain. Selain muda-mudi yang kurang aktif tersebut, terdapat juga muda-mudi yang selalu meluangkan waktudan tenaganya untuk membantu setiap kegiatan PMVB. Berdasarkan wawancara lain yang dilakukan terhadap tujuh muda-mudi yang aktif membantu, baik di acara keagamaan maupun sosial, mengatakan bahwa mereka senang berbagi dan mendapat pengalaman baru, merasakan kehidupan mereka ternyata jauh lebih baik dan lebih menghargai apa yang dimilikinya saat ini. Selain itu, ada pula yang mengatakan ia baru menyadari ternyata banyak orang-orang yang masih sangat berkekurangan sehingga memunculkan niat untuk berbagi.

Banyak faktor di balik perilaku prososial yang dapat meningkatkan maupun menurunkan perilaku tersebut. Salah satu faktor yang dapat meningkatkan perilaku prososial adalah rasa syukur.Emmons (2007), mendefinisikan rasa syukur dalam dua kategori, yaitu pertama, bersyukur adalah pengakuan kebaikan dalam kehidupan seseorang. Pengakuan yang mana seseorang menerima sesuatu yang memuaskan, baik dengan kehadirannya atau dengan usaha yang diberikan oleh pemberi. Kedua, bersyukur adalah pengakuan bahwa sumber kebaikan ini setidaknya sebagian berada di luar diri. Objek rasa syukur seseorang seperti kepada orang lain, kepada Tuhan, pada hewan, tetapi tidak pada dirinya sendiri melainkan kepada pemberi hadiah atau bantuan. Watkins, Woodward, Stone, dan Kolts (2003) membuktikan orang yang bersyukur akan merasa melimpah, apresiasi terhadap hal sederhana, apresiasi terhadap orang lain dan faktor-faktor ini berfungsi untuk menumbuhkan sikap yang lebih umum yang memandang kehidupan sebagai hadiah.

Ada beberapa penelitian mengenai pengaruh rasa syukur terhadap perilaku prososial, seperti penelitian yang dilakukan oleh Tsang (2006) ditemukan bahwa peraasaan syukur dapat meningkatkan suasana hati yang positif danmemotivasi individu berperilaku prososial kepada orang yang telah memberikan bantuan 
kepadanya. Secara mendalam, rasa syukur merupakan emosi prososial. Penelitian yang dilakukan oleh Wangwan (2014) juga menunjukkan perasaan positif, apresiasi, dan perasaan berhutang budi dapat memotivasi seseorang untuk berperilaku prososial kepada orang yang telah membantunya. Nowak dan Roch (dalam McCullough, Kimeldorf,\& Cohen, 2008) menyarankan bahwa rasa syukur memungkinkan hubungan timbal balik hulu. Hubungan antara rasa syukur dan perilaku prososial tidak hanya antara penolong dengan penerima pertolongan tetapi juga hubungan antara penerima pertolongan dengan orang lain. Penelitian Bartlett dan DeSteno (2006) juga menunjukkan bahwa rasa syukur dapat meningkatkan perilaku prososial kepada pemberi bantuan dan ditemukan individu yang merasa bersyukur tersebut juga memberikan bantuan kepada pihak ketiga yang tidak berhubungan, namun hal ini dinyatakan sebagai efek kebetulan.

Berdasarkan paparan di atas dan di dukung oleh beberapa penelitian terdahulu, peneliti ingin membuktikanbahwa individu yang bersyukur dalam kehidupan sehari-harinya akan mempengaruhi tingkat perilaku prososialnya. Dengan hasil penelitian ini diharapkan dapat memberikan wawasan mengenai manfaat rasa syukur terhadap kesejahteraan banyak orang.Dalam penelitian ini, hipotesis yang diajukan adalah rasa syukur memiliki pengaruh positif terhadap perilaku prososial.

\section{Metode}

Penelitian ini menggunakan metode penelitian kuantitatif dengan pendekatan korelasional dua variabel. Penelitian ini bertujuan untuk menguji hubungan antara rasa syukur dengan perilaku prososial.

Populasi dalam penelitian ini adalah 260 muda-mudi di Persaudaraan Muda-Mudi Vihara Borobudur Medan. Teknik pengambilan sampel yang digunakan adalah teknik purposive sampling dengan kriteria muda-mudi telah menjadi anggota minimal satu tahun dan berusia 18-40 tahun sehingga diperoleh 149 partisipan. Adapun alasan penggunaan teknik purposive sampling karena muda-mudi yang telah bergabung minimal satu tahun telah mengetahui kondisi lingkungan organisasi dan pernah menjadi panitia kegiatan. 
Penelitian mengenai hubungan antara rasa syukur dengan perilakuprososial terdiri dari dua skala, antara lain skalarasa syukur dan perilaku prososial. Skala rasa syukur dikembangkan berdasarkan faset-faset rasa syukur yang dikemukakan oleh McCullough, Emmons, \& Tsang (2002) yang meliputi faset intensity, frequency, span, dan density.Kemudian skala perilaku prososial disusun berdasarkan aspek yang dikemukakan oleh Schroeder dan Graziano (2015), yaitu menolong, altruisme, sukarela, dan kerja sama.

Aitem yang valid berdasarkan nilai koefisien yang dinyatakan oleh Azwar (2016), yaitu ditinjau dari nilai $r \geq 0,30$.Berdasarkan hasil uji validitas aitem dengan menggunakan rumus corrected item total correlation, terdapat 33 aitem (18 aitem favourable dan 15 aitem unfavourable) yang valid untuk skala rasa syukurdan 27 aitem (16 aitem favourable dan 11 aitem unfavourable) yang valid untuk skala perilaku prososial, kemudian skala dibuat dalam satu eksemplar. Adapunkoefisien reliabilitas alat ukur rasa syukur $(\alpha=0,889)$ dan perilaku prososial $(\alpha=0,903)$.

Skala penelitian ini menggunakan skala Likert dengan empat pilihan jawaban yaitu SS (sangat setuju), S (setuju), TS (tidak setuju), dan STS (sangat tidak setuju). Aitem favourable memiliki skor yang bergerak dari 4-1, sedangkan aitem unfavourable memiliki skor yang bergerak dari 1-4.

Teknik analisis yang digunakan untuk menganalisis data hasil penelitian ini adalah teknik Pearson Product Moment Correlation dengan menggunakan program SPSS 21 forwindows. Teknik analisis diatas dilakukan setelah melakukan uji asumsi klasik yang meliputi uji normalitas dengan rumus Kolmogorov Smirnov $Z$ dan uji linearitas hubungan dengan test linearity dalam program SPSS 21 forwindows.

\section{Hasil dan Pembahasan}

Pada penelitian ini subjek yang terlibat dalam penelitian berjumlah 149 orang. Pada skor variabel perilaku prososial, hasil analisis untuk skala perilaku prososial diperoleh mean empirik < mean hipotetik, yaitu 82,42 > 67,5. 
Selanjutnya subjek dibagi ke dalam tiga norma kategori perilaku prososial, yaitu perilaku prososial rendah, sedang, dan tinggi (Azwar, 2016).

Berdasarkan proses ini diperoleh subjek yang masuk dalam kategori rendah sebesar 0 (nol) subjek (0\%), sedangkan perilaku prososial pada subjek yang masuk dalam kategori sedang berjumlah 64 subjek (43\%), dan perilaku prososial pada subjek yang masuk dalam kategori tinggi berjumlah 85 subjek (57\%). Hasil kategorisasi data perilaku prososial dapat dilihat pada Tabel 1.

Sementara pada skor variabel rasa syukur, hasil analisis untuk skala rasa syukur diperoleh mean empirik < mean hipotetik, yaitu 101,43> 82,5. Berdasarkan proses ini diperoleh subjek yang masuk dalam kategori rendah sebesar 0 (nol) subjek (0\%), sedangkan rasa syukur pada subjek yang masuk dalam kategori sedang berjumlah 58 subjek (39\%), dan rasa syukur pada subjek yang masuk dalam kategori tinggi berjumlah91 subjek (61\%). Hasil kategorisasi data perilaku prososial dapat dilihat pada Tabel 2.

Tabel 1. Kategorisasi Data Perilaku Prososial

\begin{tabular}{ccccc}
\hline Variabel & Rentang Nilai & Kategori & Jumlah (n) & Persentase \\
\hline \multirow{3}{*}{ Perilaku Prososial } & $\mathrm{x}<54$ & Rendah & 0 & $0 \%$ \\
& $54 \leq \mathrm{x}<81$ & Sedang & 64 & $43 \%$ \\
& $\mathrm{x} \geq 81$ & Tinggi & 85 & $57 \%$ \\
\hline & Total & & $\mathbf{1 4 9}$ & $\mathbf{1 0 0 \%}$
\end{tabular}

Tabel 2. Kategorisasi Data Rasa Syukur

\begin{tabular}{ccccc}
\hline Variabel & Rentang Nilai & Kategori & Jumlah (n) & Persentase \\
\hline \multirow{3}{*}{ Rasa Syukur } & $\mathrm{x}<66$ & Rendah & 0 & $0 \%$ \\
& $66 \leq \mathrm{x}<99$ & Sedang & 58 & $39 \%$ \\
& $\mathrm{x} \geq 99$ & Tinggi & 91 & $61 \%$ \\
\hline & Total & & $\mathbf{1 4 9}$ & $\mathbf{1 0 0 \%}$ \\
\hline
\end{tabular}

Sebelum melakukan uji hipotesis, akan dilakukan uji asumsi untuk mengetahui ada tidaknya penyimpangan data yang diperoleh dari alat pengumpulan data. Uji asumsi yang digunakan dalam penelitian ini adalah uji normalitas dan uji linearitas. 
Tabel 3. Hasil Uji Normalitas

\begin{tabular}{cccccc}
\hline Variabel & SD & K-SZ & Sig. & p & Keterangan \\
\hline Perilaku Prososial & 9,951 & 0,507 & 0,4795 & $\mathrm{p}>0,05$ & Sebaran normal \\
Rasa Syukur & 12,183 & 0,458 & 0,4925 & $\mathrm{p}>0,05$ & Sebaran normal \\
\hline
\end{tabular}

Pada Tabel 3 variabel perilaku prososial menunjukkan nilai K-SZ sebesar 0,507 dengan Sig sebesar 0,479 ( $\mathrm{p}>0,05)$ sedangkan variabel rasa syukur menunjukkan K-SZ sebesar 0,458 dengan Sig sebesar 0,492 Sig. 1-tailed ( $\mathrm{p}>$ 0,05), artinya sebaran skor perilaku prososial dan rasa syukur mengikuti distribusi normal (Priyatno, 2017).

Tabel 4. Hasil Uji Liniearitas

\begin{tabular}{cccc}
\hline Variabel & F & Sig. & Keterangan \\
\hline $\begin{array}{c}\text { Perilaku Prososial } \\
\text { Rasa Syukur }\end{array}$ & 80,438 & 0,000 & Linear $(\mathrm{p}<0,05)$ \\
\hline
\end{tabular}

Pada Tabel 4 nilai $\mathrm{p}$ yang diperoleh yaitu 0,000 maka $\mathrm{p}<0,05$ maka dapat disimpulkan bahwa kedua variabel memiliki hubungan yang linear dan memenuhi syarat untuk menggunakan analisis Pearson Product Moment Correlation (Priyatno, 2017).

Tabel 5. Hasil Uji Hipotesis

\begin{tabular}{ccc}
\hline Analisis & Pearson Correlation & Signifikansi (p) \\
\hline Korelasi & 0,551 & 0,000 \\
\hline
\end{tabular}

Pada Tabel 5 hasil analisis korelasi antara rasa syukur dan perilaku prososial, diperoleh koefisien Pearson Product Moment Correlation sebesar 0,551 dengan $\mathrm{p}$ sebesar 0,000 ( $\mathrm{p}<0,05$; Sig. 1-tailed). Hal ini menunjukkan bahwa adanya korelasi positif antara rasa syukur dan perilaku prososial yang berarti semakin tinggi rasa syukur maka semakin tinggi perilaku prososial dan begitu pula sebaliknya.

Tabel 6. Sumbangan Efektif

\begin{tabular}{ccccc}
\hline Model & R & R Square & Adjusted $\boldsymbol{R}$ Square & Std. Error of the Estimate \\
\hline 1 & 0,551 & 0,303 & 0,298 & 8,335 \\
\hline
\end{tabular}


Berdasarkan Tabel 6 dapat disimpulkan dalam penelitian ini diperoleh koefisiendeterminasi sebesar 0,303 (30,3\%).McCullough, Tsang, danEmmons (2004) menyatakan bahwaorang yang memiliki rasa syukur yang tinggi cenderung memiliki kepuasan hidup yang tinggi, suka menolong, lebih berempati, pemaaf, memiliki spiritualitas dan religiusitas yang tinggi, lebih bahagia, serta memiliki harapan yang tinggi dalam hidupnya. Sebaliknya orang yang memiliki rasa syukur yang rendah akan lebih cenderung mengalami depresi, membenci, dan iri hati terhadap orang lain. Hal senada juga disampaikan oleh Emmons (2007) bahwa orang-orang yang bersyukur mengalami peningkatan emosi positif seperti kegembiraan, antusiasme, cinta, kebahagiaan, optimisme, dan dengan praktik bersyukur sebagai disiplin hidup melindungi seseorangdari dorongan perasaan iri, dendam, keserakahan, dan kebencian. Penelitian mereka juga menyimpulkan bahwa rasa syukur mengarah pada meningkatnya perasaan saling terhubung, memperbaiki hubungan, dan bahkan altruisme. Mereka juga menemukan bahwa ketika seseorangbersyukur, mereka merasa lebih mencintai, lebih mudah memaafkan, dan lebih dekat dengan Tuhan.

Rasa syukur penting bagi kehidupan karena dapat mendatangkan hal positif dalam dunia sosial seseorang. Rasa syukur memperkuat kesadaran dan penilaian seseorang terhadap kebaikan orang lain kepada mereka. Ketika seseorang secara rutin mengalami dan mengungkapkan rasa syukur, mereka menjadi lebih sadar akan kebaikan yangdilakukan orang lain untuk mereka, dan kebaikan yang mereka rasakan dalam diri orang lain diperkuat. Dengan cara ini, pengalaman bersyukur mendorong pandangan yang lebih positif tentang dunia sosial seseorang sehingga ia lebih mudah mendeteksi hal-hal positif di lingkungan sekitarnya (Watkins, 2014).

McCullough, Kilpatrick, Emmons, \& Larson (2001) menyatakan bahwa rasa syukur merupakan bagian dari afek moral. Sebagai motif moral, rasa syukur mendorongseseorang untuk memberi respon dengan cara yang ramah dan prososial kepada orang yang telah membantunya maupun kepada orang lain. Menurut Visser (2009), ketika penerima bantuan menjadi pemberi bantuan, 
perasaan bersyukur ini berkembang menjadi poros antara kebaikan pertama dan berikutnya, ini dimulai sebagai reaksi dan pengakuan kebaikan, dan kemudian setelah refleksi lebih lanjut berubah menjadi motivator. Fredrickson (dalam Emmons \& McCullough, 2004) dalam pemeriksaannya tentang hubungan antara rasa syukur dan emosi positif, menulis bahwa orang-orang yang bersyukur tampak kreatif ketika mereka merumuskan tindakan yang mempromosikan kesejahteraan orang lain. Kesimpulannya, rasa syukur memperluas cara berpikir orang-orang karena mereka secarakreatif mempertimbangkan beragam tindakan yang mungkin bermanfaat bagi orang lain. Meskipun orang yang bersyukur biasanya melakukan tindakan prososial hanya sebagai ungkapan rasa syukurnya, seiring waktu, tindakan yang terinspirasi oleh rasa syukur membangun dan memperkuat ikatan sosial.

Sebagai penguat moral, rasa syukur berfungsi meningkatkan perilaku prososial orang yang menerima ungkapan syukur, baik kepada pemberi ungkapan syukur maupun pada orang lain (McCullough, Kilpatrick, Emmons \& Larson, 2001). Hal ini juga didukung oleh penelitian yang dilakukan oleh Grant dan Gino (2010) yang menyatakan bahwa rasa syukur tidak hanya berpengaruh positif terhadap orang yang menerima kebaikan tetapi juga kepada orang yang memberikan bantuan. Individu yang menerima ungkapan syukur karena pertolongannya membuat individu tersebut mempertahankan perilaku prososialnya di kesempatan lain.

Pada akhirnya, rasa syukur yang dirasakan oleh seseorang akan membantunya untuk membalas kebaikan yang ia hayati. Kebaikan yang merupakan balasan dari rasa syukur yang dimiliki kemudian akan menghasilkan kebaikan lainnya. Pendapat ini diikuti oleh hasil penelitian lainnya yang menunjukkan bahwa dengan adanya rasa syukur maka seseorang akan cenderung lebih mampu berperilaku prososial atau menolong orang lain bahkan pada pertolongan yang membutuhkan upaya yang besar (Barlett \& DeSteno, 2006), memiliki tanggung jawab sosial (McCullough, Kilmerdorf,\& Cohen, 2008), hingga menurunkan kecenderungan materialisme (Polak \& McCullough, 2006). 
Berdasarkan hasil kategorisasi data perilaku prososial terlihat tidak terdapat subjek yang memiliki perilaku prososial rendah, terdapat 64 subjek (43\%) yang memiliki perilaku prososial sedang dan terdapat 85 subjek (57\%) yang memiliki perilaku prososial tinggi. Kondisi ini terlihat sedikit bertolak belakang mengingat rendahnya perilaku prososial pada muda-mudi. Perbedaan kondisi ini terjadi karena masih kurangnya inisiatif muda-mudi untuk membantu sehingga perlu diminta untuk membantu, selain itu peneliti juga hanya melihat dari segi keaktifan muda-mudi dalam kegiatan Persaudaraan Muda-Mudi Vihara Borobudur Medan namun kurang melihat lebih mendalamaspek-aspek perilaku prososial lainnya.

Pada penelitian ini diperoleh koefisien determinasi R Square (R2) sebesar 0,303. Berdasarkan hasil tersebut, dapat disimpulkan bahwa 30,3\% rasa syukur mempengaruhi perilaku prososial anggota Persaudaraan Muda-mudi Vihara Borobudur Medan dan sisanya 69,7\% dipengaruhi faktor lain yang tidak diteliti dalam penelitian ini. Perilaku prososial terbentuk karena banyak faktor seperti faktor personal, interpersonal atau situasional (Rahman, 2013). Faktor-faktor lain yang dapat mempengaruhi perilaku prososial seseorang seperti empati (Asih \& Pratiwi, 2010; Istiana, 2016), kematangan emosi (Asih \& Pratiwi, 2010; Haryati, 2013), religiusitas (Haryati, 2013), pola asuh demokratis dan kecerdasan emosi (Husada, 2013) kepribadian big five (Wisudiani \& Fardana, 2014), kecerdasan spiritual (Yantiek, 2014; Wahyuni, Mayangsari,\& Fauzia, 2016), ketertarikan interpersonal (Sari \& Siswati, 2016) dan harga diri (Lupitasari \& Fauziah, 2017).

\section{Kesimpulan dan Saran}

\section{Kesimpulan}

Berdasarkan hasil penelitian ini, ditemukan ada hubungan positif antara rasa syukur dengan perilaku prososial dengan nilai koefisien Pearson Product Moment Correlation sebesar 0,551 dengan p sebesar 0,000 ( $p<0,05$; Sig. 1 tailed). Hubungan positif memiliki arti bahwa semakin tinggi tingkat rasa syukur yang dimiliki muda-mudi maka semakin tinggi pula perilaku prososial pada muda-mudi dan sebaliknya, semakin rendah tingkat rasa syukur, maka semakin 
rendah pula perilaku prososial pada muda-mudi. Individu yang bersyukur akan memberikan manfaat yang besar bagi diri sendiri maupun kepada orang lain karena rasa syukur menimbulkan pandangan yang positif terhadap lingkungan sekitarnya dan dapat meningkatkan kesejahteraan hidup seseorang.

\section{Saran}

Berdasarkan hasil penelitian ini, diharapkan ketua dan para pengurus Persaudaraan Muda-Mudi Vihara Borobudur Medan dapat memberikan pelatihanpelatihan berkesadaran yang dapat meningkatkan rasa syukur kepada para mudamudi sehingga dapat secara konsisten memberi pelayanan dan membantu masyarakat.

Bagi peneliti selanjutnya diharapkan dapat mencari faktor lain yang turut mendorong kecenderungan rasa syukur dan perilaku prososial. Penelitian selanjutnya juga diharapkan dapat menggali lebih dalam mengenai pengaruh rasa syukur terhadap perilaku prososial individu yang menerima ungkapan rasa syukur dalam perilaku prososialnya. Selain itu, diharapkan dapat lebih mengembangkan aitem pernyataan berdasarkan aspek-aspek dari dua variabel sehingga akan mendapatkan hasil yang lebih baik.

\section{DAFTAR PUSTAKA}

Algoe, S. B., Haidt, J., \& Gable, S. L. (2008). Beyond reciprocity: Gratitude and relationships in everyday life. Emotion, 8, 425- 429.

Asih, G. Y., \& Pratiwi, M. M. S. (2010). Perilaku prososial ditinjau dari empati dan kematangan emosi. Jurnal Psikologi: Pitutur, 1 (1), 33-42.

Azwar, S. (2016). Penyusunan skala psikologi. Yogyakarta: Pustaka Pelajar.

Bartlett, M. Y., \& DeSteno, D. (2006). Gratitude and prosocial behavior: Helping when it costs you. Psychological Science, 17 (4), 319-325.

Baron, R. A., \& Byrne, D. (2003). Social Psychology $\left(10^{\text {th }}\right.$ ed). New Jersey: Pearson Education, Inc. Emmons, R. A. (2007). Thanks!: How the new science of gratitude can make you happier. New York: Houghton Mifflin Company. 
Emmons, R. A., \& McCullough, M. E. (2004). The psychology of gratitude. New York: Oxford University Press.

Froh, J. J., Bono, G., Emmons, R. (2010). Being grateful is beyond good manners: Gratitude and motivation to contribute to society among early adolescents. Motivation and Emotion, 34 (2), 144-157.

Grant, A. M., \& Gino, F. (2010). A little thanks goes a long way: Explaining why gratitude expressions motivate prosocial behavior. Journal of Personality and Social Psychology. 98 (6), 946-955.

Haryati, T. D. (2013). Kematangan emosi, religiusitas dan perilaku prososial perawat di rumah sakit. Persona, Jurnal Psikologi Indonesia. 2 (2), 162-172.

Heinzen, T., \& Goodfriend, W. (2019). Social Psychology. London: SAGE Publications.

Herimanto \& Winarno. (2017). Ilmu sosial \& budaya dasar. Jakarta: Bumi Aksara.

Hogg, M. A., \& Vaughan, G. M. (2011). Social Psychology $\left(6^{\text {th }}\right.$ ed). England: Pearson Education Limited.

Husada, A. K. (2013). Hubungan pola asuh demokratis dan kecerdasan emosi dengan perilaku prososial pada remaja. Persona,Jurnal Psikologi Indonesia. 2 (3), 266-277.

Istiana. (2016). Hubungan empati dengan perilaku prososial pada relawan KSR PMI Kota Medan. Jurnal Diversita. 2 (2), 1-13.

Lupitasari, N., \& Fauziah, N. (2017). Hubungan antara harga diri dengan kecenderungan perilaku prososial pada remaja Panti Asuhan di Semarang. Jurnal Empati, 7 (3), 318-322.

McCullough, M. E., Emmons, R. A., \& Tsang, J. (2002). The grateful disposition: A conceptual and empirical topography. Journal of Personality and Social Psychology, 82 (1), 112-127.

McCullough, M. E., Kimeldorf, M. B., \& Cohen, A. D. (2008). An adaptation for altruism? The social causes, social effects, and social evolution of gratitude. Psychological Science, 17 (4), 281-285.

McCullough, M. E., Tsang, J., \& Emmons, R. A. (2004). Gratitude in intermediate affective terrain: Links of grateful moods to individual differences and daily emotional experience. Journal of Personality and Social Psychology. 86 (2), 295-309. 
McCullough, M. E., Kilpatrick, S., Emmons, R. A., \& Larson, D. (2001). Is gratitude a moral affect?. Psychological Bulletin, 127 (2), 249-266.

Musick, M. A., \& Wilson, J. (2008). Volunteers: A social profile. Bloomington: Indiana University Press.

Pitaloka, D. A., \& Ediati, A. (2015). Rasa syukur dan kecenderungan perilaku prososial pada mahasiswa fakultas psikologi universitas diponegoro. Jurnal Empati. 4 (2), 43-50.

Polak, E. L., \& McCullough, M, E. (2006). Is gratitude an alternative to materialism?. Journal of Happiness Studies, 7, 343-360.

Priyatno, D. (2017). Panduan praktis olah data menggunakan SPSS. Yogyakarta: Andi.

Pujileksono, S., Abdurahman, S. M., Yuliani, D., \& Wuryantari, M. (2018). Dasar-dasar praktik pekerjaan sosial: seni menjalani profesi pertolongan. Malang: Intrans Publishing.

Sari, I. K., \& Siswati. (2016). Hubungan antara ketertarikan interpersonal dengan perilaku prososial pada remaja SMA Islam Hidayatullah Semarang. Jurnal Empati, 5 (4), 711-716.

Schroeder, D.A \& Graziano, W.G. (2015). The Oxford Handbook of Prosocial Behavior. New York: Oxford University Press.

Tsang, J. A. (2006). Gratitude and prosocial behaviour: An experimental test of gratitude. Cognition and Emotion Journal. 20 (1), 138-148.

Visser, M. (2009). The gift of thanks: The roots and rituals of gratitude. New York:Houghton Mifflin Harcourt.

Wahyuni, R., Mayangsari, M. D., \& Fauzia, R. (2016). Hubungan kecerdasan spiritual dengan perilaku prososial pada perawat di rumah sakit islam banjarmasin. Jurnal Ecopsy. 3 (3), 140-143.

Wangwan, J. (2014). A moel of relationship between gratitude and prosocial motivation of thai high school and undergraduate students. International Journal of BehavioralScience, 9 (1), 15-30.

Watkins, P. C. (2014). Gratitude and the good life: Toward a psychology of appreciation. New York: Springer. 
Watkins, P. C., Woodward, K., Stone, T., \& Kolts, R. (2003). Gratitude and happiness: Development of a measure of gratitude, and relationships with subjective well-being. Social Behavior and Personality, 31 (5), 431-452.

Wisudiani, R., \& Fardana, N. A. (2014). Hubungan antara faktor kepribadian big five dengan perilaku prososial pada mahasiswa keperawatan. Jurnal Psikologi Kepribadian dan Sosial. 3 (1), 97-104.

Yantiek, E. (2014). Kecerdasan emosi, kecerdasan spiritual dan perilaku prososial remaja. Persona,Jurnal Psikologi Indonesia. 3 (1), 22-31. 